\title{
Occurrence and sequence analysis of porcine deltacoronaviruses in southern China
}

Shao-Lun Zhai ${ }^{1 \dagger}$, Wen-Kang Wei ${ }^{1 \dagger}$, Xiao-Peng Li ${ }^{1 \dagger}$, Xiao-Hui Wen ${ }^{1}$, Xia Zhou ${ }^{1}$, He Zhang ${ }^{1}$, Dian-Hong Lv ${ }^{1 *}$, Feng $\mathrm{Li}^{2,3}$ and Dan Wang ${ }^{2^{*}}$

\begin{abstract}
Background: Following the initial isolation of porcine deltacoronavirus (PDCoV) from pigs with diarrheal disease in the United States in 2014, the virus has been detected on swine farms in some provinces of China. To date, little is known about the molecular epidemiology of PDCoV in southern China where major swine production is operated.

Results: To investigate the prevalence of PDCoV in this region and compare its activity to other enteric disease of swine caused by porcine epidemic diarrhea virus (PEDV), transmissible gastroenteritis coronavirus (TGEV), and porcine rotavirus group C (Rota C), 390 fecal samples were collected from swine of various ages from 15 swine farms with reported diarrhea. Fecal samples were tested by reverse transcription-PCR (RT-PCR) that targeted PDCoV, PEDV, TGEV, and Rota C, respectively. PDCoV was detected exclusively from nursing piglets with an overall prevalence of approximate $1.28 \%(5 / 390)$, not in suckling and fattening piglets. Interestingly, all of PDCoV-positive samples were from 2015 rather than 2012-2014. Despite a low detection rate, PDCoV emerged in each province/region of southern China. In addition, compared to TGEV (1.54 \%, $5 / 390)$ or Rota C $(1.28 \%, 6 / 390)$, there were highly detection rates of PEDV $(22.6 \%, 88 / 390)$ in those samples. Notably, all five PDCoV-positive piglets were co-infected by PEDV. Furthermore, phylogenetic analysis of spike (S) and nucleocapsid (N) gene sequences of PDCoVs revealed that currently circulating PDCoVs in southern China were more closely related to other Chinese strains of PDCoVs than to those reported in United States, South Korea and Thailand.
\end{abstract}

Conclusions: This study demonstrated that PDCoV was present in southern China despite the low prevalence, and supported an evolutionary theory of geographical clustering of PDCoVs.

Keywords: Porcine deltacoronavirus, Occurrence, Spike gene, Nucleocapsid gene, Sequence analysis, Southern China

\section{Background}

Before 2012, the subfamily Coronavirinae included three genera (Alphacoronavirus, Betacoronavirus and Gammacoronavirus). However, in 2012, an emerging genus, Deltacoronavirus, was found in many animal species including swine from Hong Kong [1]. At present, more than five different coronaviruses have been described in swine populations. Among them, porcine epidemic diarrhea virus

\footnotetext{
*Correspondence: gdred@163.com; dan.wang@sdstate.edu

†Equal contributors

'Animal Disease Diagnostic Center, Institute of Animal Health, Guangdong Academy of Agricultural Sciences, Guangdong Key Laboratory of Animal

Disease Prevention, Guangdong Open Laboratory of Veterinary Public Health, Guangzhou 510640, China

${ }^{2}$ Department of Biology and Microbiology, South Dakota State University, Brookings, SD 57007, USA

Full list of author information is available at the end of the article
}

(PEDV), transmissible gastroenteritis virus (TGEV), and porcine respiratory coronavirus (PRCV) belong to the genus Alphacoronavirus; meanwhile, porcine hemagglutinating encephalomyelitis virus (PHEV) and Porcine deltacoronavirus (PDCoV) are assigned to the genus Betacoronavirus and the genus Deltacoronavirus, respectively [1]. Numerous studies have shown that more than half of porcine coronaviruses (including $\mathrm{PDCoV}$ ) were enteropathogenic and caused acute diarrhea and vomiting in pigs, which resulted in huge economic losses for the global swine industry [2-6].

Currently, PDCoV has been reported in Hong Kong, North America, Mexico, South Korea, Thailand and some provinces of China [1, 7-19]. Despite recent progress, little is known about the prevalence and epidemiology of PDCoV in southern China (including Guangdong 
province, Hainan province, and Guangxi autonomous region), where major swine production is operated. Therefore, the aim of this study was to investigate the prevalence and sequence properties of $\mathrm{PDCoV}$ in this region.

\section{Methods \\ Sampling}

A total of 390 fecal samples (Table 1) were collected from 15 commercial swine farms with reported diarrhea in southern China. Farms A, D, E, J-O were from Guangdong province, Farms B, F, G were from Hainan province, and farms $\mathrm{C}, \mathrm{H}$, I were the Guangxi autonomous region. Farms A-I derived 30 samples with the following arrangement: ten samples from suckling piglets $(<3$ weeks old), ten samples from nursing piglets (between 3 and 9 weeks old), and ten samples from fattening piglets ( $>9$ weeks old). The samples of farms A-I were collected between July and August 2015 and stored at $-80{ }^{\circ} \mathrm{C}$ until further use. However, the samples of farms J-O were archived samples from 2012 to 2014. Prior to viral RNA extraction, fecal samples were diluted one time using Phosphate Buffered Saline (PBS) $(\mathrm{pH}$ : 7.4). The supernatants were then collected by centrifugation at $5000 \times \mathrm{g}$ for $5 \mathrm{~min}$. $200 \mu \mathrm{l}$ of clarified supernatants was used to extract viral RNA following the manufacturer's recommendations (Axygen Scientific Inc.). RNA samples were stored at $-80{ }^{\circ} \mathrm{C}$ until further analysis.

\section{Reverse transcription polymerase chain reaction (RT-PCR) detection}

To detect PDCoV genome in collected fecal samples, the previously reported RT-PCR primers (41 F: 5'-TTT CAGGTGCTCAAAGCTCA-3' and 735R: 5'-GCGAAA AGCATTTCCTGAAC-3') targeting the nucleocapsid (N) gene with reaction conditions $\left(50{ }^{\circ} \mathrm{C}\right.$ for $30 \mathrm{~min}$ and $95{ }^{\circ} \mathrm{C}$ for $15 \mathrm{~min}$ for the reverse transcription reaction, followed by 40 cycles of PCR amplification at $95{ }^{\circ} \mathrm{C}$ for $15 \mathrm{~s}, 55^{\circ} \mathrm{C}$ for $45 \mathrm{~s}$, and $72{ }^{\circ} \mathrm{C}$ for $1 \mathrm{~min}$, with a final extension at $72{ }^{\circ} \mathrm{C}$ for $7 \mathrm{~min}$ ) were used [15]. In addition, molecular detection of the three diarrhea-related enteric viruses (Porcine epidemic diarrhea virus, PEDV; Porcine transmissible gastroenteritis virus, TGEV; Porcine rotavirus group $C$, Rota $C$ ) was performed in accordance with previous methods [20-22] for further evaluation of the possible co-infection status with PDCoV in investigated pig samples.

\section{Amplification of the spike (S) and $\mathrm{N}$ genes}

To perform in-depth sequence comparison and phylogenetic analysis with known reference sequences (Additional file 1: Table S1), the complete spike (S) and $N$ genes of PDCoV-positive samples were amplified according to previously published methods [8]. For amplification of the full-length $\mathrm{S}$ and $\mathrm{N}$ genes, previously reported RT-PCR primers (PDCoV-SF2: 5'-AGCGTTGACACCAACCTA TT-3' and PDCoV-SR2: 5'-TCGTCGACTACCATTCCT TAAAC-3'; PDCoV-NF1 : 5'-CCATC GCTCCAAG TC ATTCT-3' and PDCoV-NR1: 5'-TGGGTGGGTTTAA CAGACATAG-3') were used. PCR was carried out at $50{ }^{\circ} \mathrm{C} 30 \mathrm{~min}$ and $95{ }^{\circ} \mathrm{C}$ for $5 \mathrm{~min}$, followed by 40 cycles of $98^{\circ} \mathrm{C}$ for $10 \mathrm{~s}, 55^{\circ} \mathrm{C}$ for $15 \mathrm{~s}$, and $68^{\circ} \mathrm{C}$ for 5 and $2 \mathrm{~min}$ for $\mathrm{S}$ and $\mathrm{N}$ genes, respectively; final extension was performed at $68{ }^{\circ} \mathrm{C}$ for $15 \mathrm{~min}$. Positive amplicons were cloned into the pGM-19 T vector (Tiangen Inc. Beijing). Furthermore, all positive recombinant plasmids were submitted to a sequencing company (The Beijing Genomics Institute, BGI) and sequenced at least three times. Five $S$ gene sequences and five $\mathrm{N}$ gene sequences were obtained (Additional file 1: Table S1), and have been submitted to GenBank database (accession numbers KU204694KU204701, KX534090-KX534091).

\section{Phylogenetic analysis of the $\mathrm{S}$ and $\mathrm{N}$ genes}

Sequence alignment analysis was performed using the Clustal W program implemented in DNAStar software. A phylogenetic tree was then constructed by the neighborjoining method using the Molecular Evolutionary Genetics Analysis (MEGA) software version 5.1 with 1000 bootstrap replications set at 1000 . Moreover, the possible recombination event was evaluated in the $\mathrm{S}$ and $\mathrm{N}$ genes by recombination detection program (RDP) 3.34 software.

\section{Results}

PDCoV detection

A total of 390 pig fecal samples, collected from 15 swine farms with reported diarrhea in southern China, were assessed for the presence of PDCoV and other viral enteric pathogens (PEDV, TGEV, and Rota C) by RT-PCR. As summarized in Table 1, the PDCoV genome was detected in specimens from 4 of 15 swine farms. Interestingly, the PDCoV genome was detected only in nursing piglets, and was absent in suckling piglets and fattening pigs. Although PDCoV was detected in each province/ region of southern China, its overall prevalence in the investigated pigs of various age groups $(n=390)$ was relatively low $(5 / 390,1.28 \%)$. The positive rate could be higher if only nursing piglets were included (5/150, $3.33 \%)$. In contrast, the prevalence of PEDV, another porcine coronavirus causing epidemic diarrhea, was relatively higher $(22.6 \%, 88 / 390)$. In addition, PEDV was different from $\mathrm{PDCoV}$ in that it distributed similarly between nursing (36/150, $24 \%)$ and suckling piglets (47/150, $31.3 \%$ ). Five fattening pigs from farms $\mathrm{A}, \mathrm{D}, \mathrm{F}$ and I were also tested positive for the PEDV genome. We also examined whether pigs with diarrhea harbored other enteric viruses such as TGEV and Rota C. Our results showed that the 
Table 1 Sample information and RT-PCR detection results of four diarrhea-associated viruses in pigs of various ages from 15 swine farms in southern China

\begin{tabular}{|c|c|c|c|c|c|c|}
\hline Farm & Pigs (Age) & Number $(n)$ & PDCoV & PEDV & TGEV & Rota C \\
\hline \multirow[t]{3}{*}{ A } & Suckling piglets ( $<3$ weeks old) & 10 & $0 / 10$ & $2 / 10$ & $0 / 10$ & $0 / 10$ \\
\hline & Nursery pigs ( $>3$ weeks old, $<9$ weeks old) & 10 & $2 / 10$ & $2 / 10$ & $0 / 10$ & $0 / 10$ \\
\hline & Fattening pig (>9 weeks old) & 10 & $0 / 10$ & $1 / 10$ & $0 / 10$ & $0 / 10$ \\
\hline \multirow[t]{3}{*}{ B } & Suckling piglets (<3 weeks old) & 10 & $0 / 10$ & $3 / 10$ & $0 / 10$ & $0 / 10$ \\
\hline & Nursery pigs ( $>3$ weeks old, $<9$ weeks old) & 10 & $1 / 10$ & $2 / 10$ & $0 / 10$ & $0 / 10$ \\
\hline & Fattening pig (>9 weeks old) & 10 & $0 / 10$ & $0 / 10$ & $0 / 10$ & $0 / 10$ \\
\hline \multirow[t]{3}{*}{ C } & Suckling piglets (<3 weeks old) & 10 & $0 / 10$ & $3 / 10$ & $0 / 10$ & $0 / 10$ \\
\hline & Nursery pigs ( $>3$ weeks old, $<9$ weeks old) & 10 & $1 / 10$ & $3 / 10$ & $0 / 10$ & $0 / 10$ \\
\hline & Fattening pig (>9 weeks old) & 10 & $0 / 10$ & $0 / 10$ & $0 / 10$ & $0 / 10$ \\
\hline \multirow[t]{3}{*}{ D } & Suckling piglets ( $<3$ weeks old) & 10 & $0 / 10$ & $2 / 10$ & $0 / 10$ & $0 / 10$ \\
\hline & Nursery pigs ( $>3$ weeks old, $<9$ weeks old) & 10 & $0 / 10$ & $1 / 10$ & $0 / 10$ & $2 / 10$ \\
\hline & Fattening pig (>9 weeks old) & 10 & $0 / 10$ & $1 / 10$ & $1 / 10$ & $0 / 10$ \\
\hline \multirow[t]{3}{*}{$\mathrm{E}$} & Suckling piglets (<3 weeks old) & 10 & $0 / 10$ & $1 / 10$ & $0 / 10$ & $0 / 10$ \\
\hline & Nursery pigs ( $>3$ weeks old, $<9$ weeks old) & 10 & $1 / 10$ & $2 / 10$ & $0 / 10$ & $0 / 10$ \\
\hline & Fattening pig (>9 weeks old) & 10 & $0 / 10$ & $0 / 10$ & $0 / 10$ & $0 / 10$ \\
\hline \multirow[t]{3}{*}{$\mathrm{F}$} & Suckling piglets ( $<3$ weeks old) & 10 & $0 / 10$ & $3 / 10$ & $0 / 10$ & $0 / 10$ \\
\hline & Nursery pigs ( $>3$ weeks old, $<9$ weeks old) & 10 & $0 / 10$ & $4 / 10$ & $0 / 10$ & $0 / 10$ \\
\hline & Fattening pig (>9 weeks old) & 10 & $0 / 10$ & $1 / 10$ & $2 / 10$ & $0 / 10$ \\
\hline \multirow[t]{3}{*}{ G } & Suckling piglets ( $<3$ weeks old) & 10 & $0 / 10$ & $5 / 10$ & $0 / 10$ & $0 / 10$ \\
\hline & Nursery pigs ( $>3$ weeks old, $<9$ weeks old) & 10 & $0 / 10$ & $3 / 10$ & $0 / 10$ & $0 / 10$ \\
\hline & Fattening pig (>9 weeks old) & 10 & $0 / 10$ & $0 / 10$ & $0 / 10$ & $0 / 10$ \\
\hline \multirow[t]{3}{*}{$\mathrm{H}$} & Suckling piglets ( $<3$ weeks old) & 10 & $0 / 10$ & $7 / 10$ & $0 / 10$ & $0 / 10$ \\
\hline & Nursery pigs ( $>3$ weeks old, $<9$ weeks old) & 10 & $0 / 10$ & $2 / 10$ & $0 / 10$ & $0 / 10$ \\
\hline & Fattening pig (>9 weeks old) & 10 & $0 / 10$ & $0 / 10$ & $0 / 10$ & $0 / 10$ \\
\hline \multirow[t]{3}{*}{ I } & Suckling piglets (<3 weeks old) & 10 & $0 / 10$ & $4 / 10$ & $0 / 10$ & $0 / 10$ \\
\hline & Nursery pigs ( $>3$ weeks old, $<9$ weeks old) & 10 & $0 / 10$ & $2 / 10$ & $0 / 10$ & $0 / 10$ \\
\hline & Fattening pig (>9 weeks old) & 10 & $0 / 10$ & $2 / 10$ & $0 / 10$ & $0 / 10$ \\
\hline \multirow[t]{2}{*}{ J } & Suckling piglets ( $<3$ weeks old) & 10 & $0 / 10$ & $4 / 10$ & $0 / 10$ & $0 / 10$ \\
\hline & Nursery pigs ( $>3$ weeks old, $<9$ weeks old) & 10 & $0 / 10$ & $3 / 10$ & $0 / 10$ & $0 / 10$ \\
\hline \multirow[t]{2}{*}{ K } & Suckling piglets (<3 weeks old) & 10 & $0 / 10$ & $5 / 10$ & $0 / 10$ & $2 / 10$ \\
\hline & Nursery pigs ( $>3$ weeks old, $<9$ weeks old) & 10 & $0 / 10$ & $5 / 10$ & $2 / 10$ & $0 / 10$ \\
\hline \multirow[t]{2}{*}{ L } & Suckling piglets (<3 weeks old) & 10 & $0 / 10$ & $2 / 10$ & $0 / 10$ & $0 / 10$ \\
\hline & Nursery pigs ( $>3$ weeks old, $<9$ weeks old) & 10 & $0 / 10$ & $0 / 10$ & $0 / 10$ & $0 / 10$ \\
\hline \multirow[t]{2}{*}{ M } & Suckling piglets (<3 weeks old) & 10 & $0 / 10$ & $2 / 10$ & $0 / 10$ & $0 / 10$ \\
\hline & Nursery pigs ( $>3$ weeks old, $<9$ weeks old) & 10 & $0 / 10$ & $3 / 10$ & $0 / 10$ & $0 / 10$ \\
\hline \multirow[t]{2}{*}{ N } & Suckling piglets ( $<3$ weeks old) & 10 & $0 / 10$ & $2 / 10$ & $0 / 10$ & $1 / 10$ \\
\hline & Nursery pigs ( $>3$ weeks old, $<9$ weeks old) & 10 & $0 / 10$ & $1 / 10$ & $0 / 10$ & $0 / 10$ \\
\hline \multirow[t]{2}{*}{ O } & Suckling piglets ( $<3$ weeks old) & 10 & $0 / 10$ & $2 / 10$ & $0 / 10$ & $0 / 10$ \\
\hline & Nursery pigs ( $>3$ weeks old, $<9$ weeks old) & 10 & $0 / 10$ & $3 / 10$ & $1 / 10$ & $0 / 10$ \\
\hline Total & & 390 & $5 / 390$ & $88 / 390$ & $6 / 390$ & $5 / 390$ \\
\hline
\end{tabular}

low detection rates $(1.54 \%, 5 / 390$ for TGEV vs $1.28 \%$, $6 / 390$ for Rota C) of the two pathogens were present in those pig samples. Intriguingly, co-infection of pigs by
PDCoV and PEDV was observed (Table 1). All PDCoV positive nursing piglets were also tested positive for PEDV, thereby indicating a $100 \%$ co-infection rate. 
Sequence comparison and phylogenetic analysis of the $S$ gene of PDCoVs

The full-length sequences of $\mathrm{S}$ genes in five PDCoVpositive samples from the four different farms were amplified and designated provisionally CH/GD01/2015, CH/GD02/2015, CH/GD03/2015, CH/HN01/2015, and $\mathrm{CH} / \mathrm{GX01/2015}$, respectively. Sequencing results showed that they were composed of 3480 nucleotides (nt). Compared to all published American and individual Asian strains (including HKU15-44, CHN-AH-2004, KNU1404, PDCoV/Swine/Thailand/S5015L/2015 and PDCoV/ Swine/Thailand/S5011/2015), a 3-nt deletion in the S gene was identified in the five current PDCoV strains, six other Chinese viral strains and one Thai viral strain reported previously (Additional file 1 : Table S1) $[5,17,18]$. Sequence alignment results revealed that $\mathrm{CH} / \mathrm{GD} 01 / 2015$, CH/GD02/ 2015, CH/GD03/2015, CH/HN01/2015 and CH/GX01/ 2015 had $>99.9 \%$ homology in the $\mathrm{S}$ gene nucleotide sequence, indicating these five viral strains evolved from the same ancestor (Table 2). Further analysis showed that the five viruses reported in this study had the highest nucleotide identity (98.9 to $99.5 \%$ ) with a Jiangxi strain (PDCoV/ CHJXNI2/2015) isolated from Jiangxi province bordering with the northern region of Guangdong province, and possessed the lowest nucleotide similarity (95.4 to $95.9 \%$ ) with PDCoV/Swine/Thailand/S5011/2015 and PDCoV/ Swine/Thailand/S5015L/2015, isolated from Thailand (Table 2). From the above data, phylogenetic analysis of the $\mathrm{S}$ gene showed that the current PDCoVs circulating in southern China were most closely related to other Chinese PDCoV isolates than to those isolated previously from USA, South Korea and Thailand (Fig. 1). In addition, in the $\mathrm{S}$ gene, any possible recombinant events were not detected among those PDCoV strains.

\section{Sequence comparison and phylogenetic analysis of the $\mathrm{N}$ gene of PDCoVs}

Similarly, N gene sequences of all five PDCoV-positive samples were identified as $1029 \mathrm{nt}$ in size. Sequence alignment results suggested that there was no deletion or insertion in $\mathrm{N}$ gene regions (Additional file 1: Table S1). Consistent with the data of $\mathrm{S}$ gene, multiple sequence alignment results of $\mathrm{N}$ gene showed that CH/GD01/2015, CH/GD02/2015, CH/ GD03/2015, CH/HN01/2015 and CH/GX01/2015 had the highest nucleotide homology (99.1 to $99.7 \%$ ) with PDCoV/ CHJXNI2/2015, and the lowest nucleotide homology (96.9 to $97.1 \%$ ) with $\mathrm{PDCoV} /$ Swine/Thailand/S5011/2015 and PDCoV/Swine/Thailand/ S5015L/2015 (Table 2). In addition, in the phylogenetic tree based on $\mathrm{N}$ gene, PDCoVs were divided into three main branches (Chinese branch, American branch and Thai branch). The five viral isolates reported from this work were clustered together within the Chinese branch (Fig. 2). Moreover, there were no any possible recombinant events occurring at the $\mathrm{N}$ gene of those PDCoV strains.

\section{Discussion \\ Epidemiology of PDCoVs}

PDCoV was first identified by Deltacoronavirus specificPCR in rectal swabs of pigs $(10.1 \%, 17 / 169)$ with unknown healthy status in Hong Kong [1]. Then, PDCoV emerged in United States, China, South Korea and Thailand $[5,17,18]$. In most of studies, excluding PEDV, TGEV and porcine rotavirus, PDCoV, as an important enteric pathogen, was detected in clinical samples from pigs with diarrhea [9-12, 23]. In addition, it was confirmed experimentally that less than two-week old piglets were susceptible to PDCoV, which caused mild to moderate diarrhea as well as macroscopic and microscopic lesions in small intestines of conventional piglets (5-day-old), and severe diarrhea, vomiting, fecal shedding of virus, and severe atrophic enteritis in gnotobiotic pigs (11- to 14-dayold) $[2,3]$. The data further confirmed that PDCoV were enteropathogenic in pigs. Meanwhile, PEDV or rotavirus showed higher detection rates in PDCoV-positive samples compared with other TGEV and rotavirus [8, 13-15, 24]. As shown above, co-infection of PDCoV and PEDV occurred in nursing piglets (Table 1), indicating that the diarrhea-related pathogens were quite complex clinically and not easy to control in the field. Moreover, in the two recent studies, PDCoV was shown to have higher infectivity in sows with diarrhea $(81.0 \%, 34 / 42)$ than nonclinical counterparts $(23.5 \%, 4 / 17)[8,15]$, which might imply that sows often carry PDCoV. And further, it could result in the transmission of PDCoV from sows to the foetus and even newborn piglets, although the pathogenesis mechanism of PDCoV remains unclear.

To further understand the origin of PDCoV, some retrospective studies were made using PCR and enzyme-linked immunosorbent assay (ELISA) [24-26]. In Dong et al. [24] study, 2 of 6 samples collected from Anhui Province of China in 2004 were positive for PDCoV, up to now, it was the most ancient time for the detection of $\mathrm{PDCoV}$ in China. Meanwhile, PDCoV could date back to August 2013 in United States, where only 3 PDCoV-samples were detected using PCR in archived samples [25]. As for serology of PDCoV, anti-PDCoV IgG antibodies could date back to 2010 using an indirect anti-PDCoV IgG ELISA based on the putative S1 portion of the spike protein [26]. The above studies indicated that PDCoV could have circulated in China at least since 2004 and in United States since 2010. Maybe, due to limted samples in the present study, we did not detect PDCoV in pig samples collected from Guangdong province between 2012 and 2014. Although Asian leopard cat coronavirus (GenBank accession no. EF584908) was close to PDCoV in the phylogenetic trees (Figs. 1 and 2), in the future, more 
Table 2 Nucleotide similarities (\%) of S and N genes of our five PDCoV isolates and other reported PDCoVs and coronaviruses

\begin{tabular}{|c|c|c|c|c|c|c|c|c|c|c|c|}
\hline \multirow{3}{*}{ GenBank No. } & \multirow[b]{3}{*}{ Strain } & \multicolumn{5}{|l|}{ S gene } & \multicolumn{5}{|l|}{$\mathrm{N}$ gene } \\
\hline & & KU204694 & KU204695 & KU204696 & KU204697 & KX534090 & KU204698 & KU204699 & KU204700 & KU204701 & KX534091 \\
\hline & & $\begin{array}{l}\mathrm{CH} / \mathrm{GD} 01 / \\
2015\end{array}$ & $\begin{array}{l}\mathrm{CH} / \mathrm{GD} 02 / \\
2015\end{array}$ & $\begin{array}{l}\mathrm{CH} / \mathrm{HNO} 01 / \\
2015\end{array}$ & $\begin{array}{l}\mathrm{CH} / \mathrm{G} \times 01 / \\
2015\end{array}$ & $\begin{array}{l}\mathrm{CH} / \mathrm{GD} 03 / \\
2015\end{array}$ & $\begin{array}{l}\mathrm{CH} / \mathrm{GD} 01 / \\
2015\end{array}$ & $\begin{array}{l}\mathrm{CH} / \mathrm{GD} 02 / \\
2015\end{array}$ & $\begin{array}{l}\mathrm{CH} / \mathrm{HN} 01 / \\
2015\end{array}$ & $\begin{array}{l}\mathrm{CH} / \mathrm{G} \times 01 / \\
2015\end{array}$ & $\begin{array}{l}\mathrm{CH} / \mathrm{GD} 03 / \\
2015\end{array}$ \\
\hline KR131621 & PDCoV/CHJXNI2/2015 & 99.5 & 98.9 & 98.9 & 99.1 & 99.2 & 99.7 & 99.1 & 99.1 & 99.3 & 99.4 \\
\hline KP757892 & CHN-JS-2014 & 99.1 & 98.5 & 98.5 & 98.7 & 98.7 & 99.3 & 99.3 & 99.3 & 99.5 & 99.0 \\
\hline KP757891 & CHN-HB-2014 & 98.9 & 98.4 & 98.4 & 98.7 & 98.5 & 98.8 & 98.6 & 98.6 & 98.8 & 98.5 \\
\hline JQ065042 & HKU15-44 & 98.6 & 98.2 & 98.2 & 98.5 & 98.3 & 98.7 & 98.5 & 98.5 & 98.7 & 98.4 \\
\hline JQ065043 & HKU15-155 & 98.5 & 98.2 & 98.2 & 98.4 & 98.2 & 98.7 & 98.5 & 98.5 & 98.7 & 98.4 \\
\hline KT021234 & $\mathrm{CH} / \mathrm{SXD} 1 / 2015$ & 98.4 & 97.9 & 97.9 & 98.1 & 98.0 & 99.0 & 98.8 & 98.8 & 99.0 & 98.7 \\
\hline KT266822 & CH/Sichuan/S27/2012 & 98.4 & 98.0 & 98.0 & 98.2 & 98.0 & 99.2 & 99.0 & 99.0 & 99.2 & 98.9 \\
\hline KM820765 & KNU14-04 & 98.4 & 97.9 & 97.9 & 98.2 & 98.1 & 98.8 & 98.6 & 98.6 & 98.8 & 98.5 \\
\hline KJ620016 & Ml6148 & 98.4 & 97.9 & 97.9 & 98.1 & 98.0 & 98.8 & 98.6 & 98.6 & 98.8 & 98.5 \\
\hline KJ584360 & MN3092 & $-a$ & $-a$ & $-a$ & $-a$ & $-a$ & 98.8 & 98.6 & 98.6 & 98.8 & 98.5 \\
\hline KJ584358 & PA3148 & 98.4 & 98.0 & 98.0 & 98.2 & 98.0 & 98.8 & 98.6 & 98.6 & 98.8 & 98.5 \\
\hline KJ584357 & KY4813 & 98.4 & 97.9 & 97.9 & 98.1 & 98.0 & 98.8 & 98.6 & 98.6 & 98.8 & 98.5 \\
\hline KJ584355 & IL2768 & 98.4 & 97.9 & 97.9 & 98.1 & 98.0 & 98.8 & 98.6 & 98.6 & 98.8 & 98.5 \\
\hline KT381613 & $\mathrm{OH} 11846$ & 98.4 & 97.9 & 97.9 & 98.1 & 98.0 & 98.8 & 98.6 & 98.6 & 98.8 & 98.5 \\
\hline KJ601779 & $\begin{array}{l}\text { PDCoV/USA/Illinois } \\
136 / 2014\end{array}$ & 98.4 & 97.9 & 97.9 & 98.1 & 98.0 & 98.5 & 98.3 & 98.3 & 98.5 & 98.3 \\
\hline KJ481931 & $\begin{array}{l}\text { PDCoV/USA/llinois } \\
121 / 2014\end{array}$ & 98.4 & 97.9 & 97.9 & 98.1 & 98.0 & 98.5 & 98.3 & 98.3 & 98.5 & 98.3 \\
\hline KJ769231 & OhioCVM1/2014 & 98.4 & 97.8 & 97.8 & 98.1 & 98.0 & 98.3 & 98.2 & 98.2 & 98.3 & 98.1 \\
\hline KJ601777 & $\begin{array}{l}\text { PDCoV/USA/llinois } \\
133 / 2014\end{array}$ & 98.4 & 97.8 & 97.8 & 98.1 & 98.0 & 98.7 & 98.5 & 98.5 & 98.7 & 98.4 \\
\hline KJ584359 & NE3579 & 98.4 & 97.8 & 97.8 & 98.1 & 98.0 & 98.7 & 98.5 & 98.5 & 98.7 & 98.4 \\
\hline KJ584356 & SD3424 & 98.4 & 97.8 & 97.8 & 98.1 & 98.0 & 98.5 & 98.3 & 98.4 & 98.5 & 98.3 \\
\hline KJ462462 & $\mathrm{OH} 1987$ & 98.4 & 97.8 & 97.8 & 98.1 & 98.0 & 98.7 & 98.5 & 98.5 & 98.7 & 98.4 \\
\hline KJ601778 & $\begin{array}{l}\text { PDCoV/USA/llinois } \\
134 / 2014\end{array}$ & 98.3 & 97.8 & 97.8 & 98.0 & 98.0 & 98.7 & 98.5 & 98.5 & 98.7 & 98.4 \\
\hline KP995358 & $\mathrm{OH}-\mathrm{FD} 22$ & 98.3 & 97.8 & 97.8 & 98.0 & 98.0 & $-b$ & $-b$ & $-b$ & $-b$ & $-b$ \\
\hline KJ601780 & $\begin{array}{l}\text { PDCoV/USA/Ohio } \\
\text { 137/2014 }\end{array}$ & 98.3 & 97.8 & 97.8 & 98.0 & 98.0 & 98.7 & 98.5 & 98.5 & 98.7 & 98.4 \\
\hline KJ569769 & IN2847 & 98.3 & 97.8 & 97.8 & 98.1 & 98.0 & 98.8 & 98.6 & 98.6 & 98.8 & 98.5 \\
\hline KJ567050 & 8734/USA-IA/2014 & 98.3 & 97.9 & 97.9 & 98.1 & 98.0 & 98.7 & 98.5 & 98.5 & 98.7 & 98.4 \\
\hline KP981395 & & 98.3 & 97.8 & 97.8 & 98.0 & 97.9 & 98.7 & 98.5 & 98.5 & 98.7 & 98.4 \\
\hline
\end{tabular}


Table 2 Nucleotide similarities (\%) of S and N genes of our five PDCoV isolates and other reported PDCoVs and coronaviruses (Continued)

\begin{tabular}{|c|c|c|c|c|c|c|c|c|c|c|c|}
\hline & $\begin{array}{l}\text { USA/IL/2014/026 } \\
\text { PDV_P11 }\end{array}$ & & & & & & & & & & \\
\hline KM012168 & Michigan/8977/2014 & 98.3 & 97.8 & 97.8 & 98.0 & 97.9 & 98.7 & 98.5 & 98.5 & 98.7 & 98.4 \\
\hline KP757890 & $\mathrm{CHN}-\mathrm{AH}-2004$ & 98.0 & 97.5 & 97.5 & 97.8 & 97.7 & 98.1 & 97.9 & 97.9 & 98.1 & 97.8 \\
\hline KU051641 & $\begin{array}{l}\text { PDCoV/Swine/Thailand/ } \\
\text { S5011/2015 }\end{array}$ & 95.8 & 95.6 & 95.6 & 95.9 & 95.4 & 97.1 & 96.9 & 96.9 & 97.1 & 96.8 \\
\hline KU051649 & $\begin{array}{l}\text { PDCoV/Swine/Thailand/ } \\
\text { S5015L/2015 }\end{array}$ & 95.8 & 95.5 & 95.5 & 95.9 & 95.4 & 97.1 & 96.9 & 96.9 & 97.1 & 96.8 \\
\hline KU984334 & P23_15_TT_1115 & 95.9 & 95.8 & 95.6 & 95.9 & 95.5 & 97.8 & 97.8 & 97.8 & 98.0 & 97.5 \\
\hline EF584908 & Guangxi/F230/2006 & 97.5 & 97.1 & 97.1 & 97.3 & 97.0 & 98.0 & 97.8 & 97.8 & 98.0 & 97.7 \\
\hline JQ065045 & HKU17-6124 & 40.9 & 40.8 & 40.8 & 40.7 & 40.7 & 92.9 & 92.6 & 92.8 & 92.9 & 92.6 \\
\hline FJ376621 & HKU12-600 & 40.7 & 41.1 & 41.1 & 41.0 & 40.6 & 76.4 & 75.7 & 76.2 & 76.3 & 76.3 \\
\hline JQ065044 & HKU16-6847 & 57.0 & 56.9 & 56.9 & 57.0 & 57.2 & 75.1 & 75.3 & 75.2 & 75.4 & 75.1 \\
\hline FJ376619 & HKU11-934 & 65.9 & 68.9 & 68.9 & 66.1 & 65.8 & 74.4 & 74.3 & 74.5 & 74.4 & 74.2 \\
\hline FJ376620 & HKU11-796 & 65.3 & 65.6 & 65.7 & 65.6 & 65.1 & 74.4 & 74.6 & 74.5 & 74.4 & 74.2 \\
\hline KJ408801 & $\mathrm{OH} 1414$ (PEDV) & 38.2 & 38.3 & 38.3 & 38.1 & 37.8 & 3.6 & 3.5 & 3.5 & 3.6 & 3.6 \\
\hline FJ755618 & H16(TGEV) & 38.1 & 38.1 & 38.1 & 38.0 & 37.9 & 2.8 & 4.9 & 7.5 & 5.0 & 2.8 \\
\hline DQ811787 & ISU-1(PRCV) & 37.4 & 25.7 & 25.7 & 25.7 & 37.3 & 7.3 & 7.4 & 7.5 & 7.4 & 7.4 \\
\hline BCU00735 & Mebus(bovine) & 12.4 & 12.5 & 12.5 & 12.4 & 7.1 & 2.1 & 2.1 & 2.1 & 2.1 & 2.1 \\
\hline AY654624 & TJF(SARS) & 6.8 & 6.9 & 6.9 & 6.8 & 6.9 & 8.8 & 8.8 & 2.4 & 8.8 & 8.1 \\
\hline DQ011855 & WW572(PHEV) & 21.9 & 21.9 & 21.9 & 21.9 & 21.8 & 2.1 & 2.1 & 2.1 & 2.1 & 2.1 \\
\hline JF893452 & $\mathrm{YN}(\mathrm{ClBV})$ & 22.0 & 22.1 & 22.1 & 22.3 & 22.0 & 12.5 & 12.5 & 12.5 & 12.6 & 12.4 \\
\hline NC_010800 & MG10 (Turkey) & 24.1 & 23.5 & 23.5 & 23.3 & 24.0 & 14.0 & 14.0 & 14.0 & 14.1 & 14.1 \\
\hline NC_010646 & SW1 (whale) & 15.0 & 13.7 & 13.7 & 13.8 & 14.8 & 7.7 & 7.7 & 7.7 & 7.7 & 7.7 \\
\hline
\end{tabular}

${ }^{\mathrm{a} S}$ gene of MN3092 was not complete; ${ }^{\mathrm{b}} \mathrm{S}$ gene of OH-FD22 was not available 


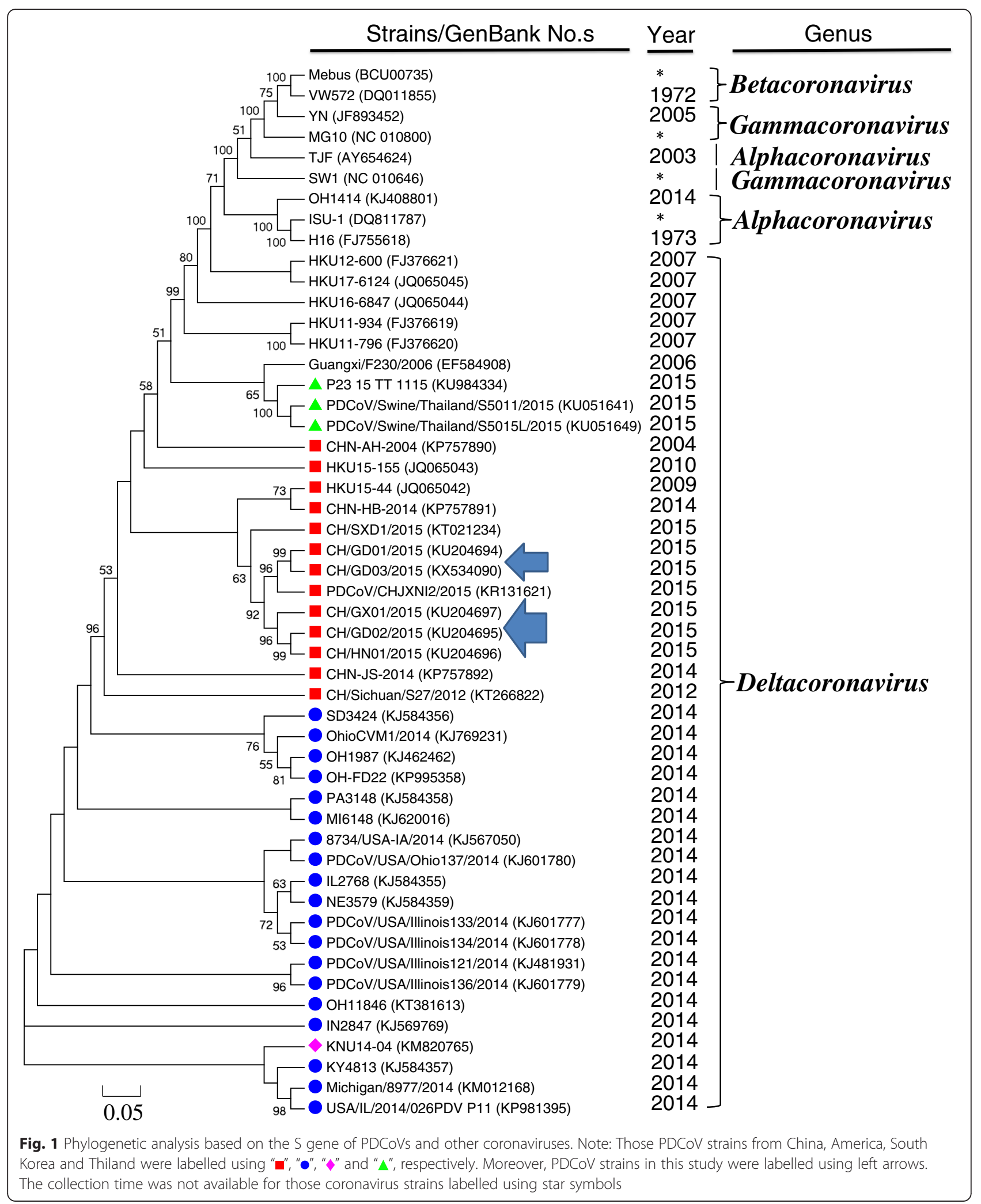




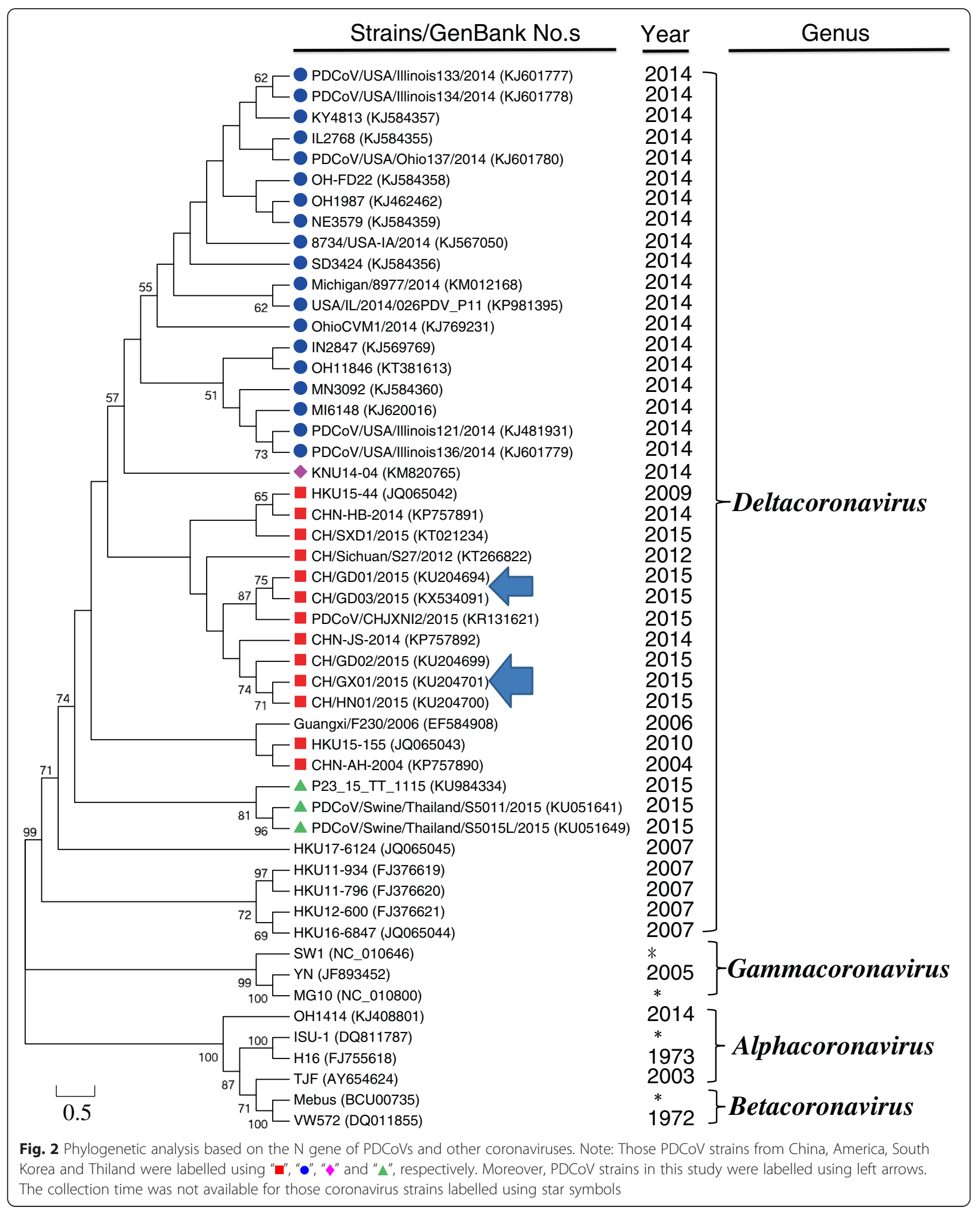


epidemiological surveys should be warranted to uncover the origin of PDCoV.

At the territory of China, Southern China mainly includes Guangdong province, Hainan province and the Guangxi autonomous region. Although molecular detection of PDCoV was performed in these regions $[23,24]$, little information was available on PDCoV prevalence. In a study by Chen et al. [23], an overall positive-PDCoV rate of $23.4 \%(15 / 64)$ was obtained in all samples collected from Guangdong, Shanxi and Hubei provinces. However, more detailed data of PDCoV was not available in Guangdong province. Meanwhile, in the study from Dong et al. [24], only four archived samples from the Guangxi autonomous region were examined, but all negative for PDCoV. In this study, we demonstrated that PDCoV circulated and was co-infected by PEDV on those swine farms in Guangdong province, Hainan province and the Guangxi autonomous region, which further contributed to the epidemiology of PDCoV in these regions despite the relatively low prevalence.

\section{Genetic diversity of PDCoVs}

The first two reported full-length PDCoV genome sequences (HKU15-44 and HKU15-155) were 25, $437 \mathrm{nt}$ and 25, $432 \mathrm{nt}$ in length, respectively [1], and they had $99.1 \%$ nucleotide similarity with each other. Moreover, further sequence alignment showed a 3-nt (TAA) insertion in the S gene and a 3-nt (TTA) insertion in the 3' untranslated region (UTR) of HKU15-44 [1, 5]. During the past 3 years, PDCoV-associated swine enteric disease was paid great attention in the major pig producing countries, especilly United States and China. Up to May 2016, more than 30 complete PDCoV genome sequences were published in the GenBank database. All were generated in China and United States except for one sequence from South Korea and three sequences from Thailand [8-19]. The Korean strain, KNU14-04, had 25, $422 \mathrm{nt}$ in length, with similar genome features (a 3-nt insertion in the S gene with 3, 483 nt and a 3-nt insertion in the 3' UTR, respectively) to all American strains and the Chinese strain (HKU15-44) [9]. Comparing complete genomes of the remaining Chinese strains to the American, Thai and Korean counterparts, CHN-HB-2014, CHN-JS-2014, PDCoV/CHJXNI2/2015, CH/Sichuan/S27/ 2012, CH/SXD1/2015 and P23_15_TT_1115 only had the 3-nt (AAT) deletion in the $\mathrm{S}$ gene (3, $480 \mathrm{nt}$ ) [14, 23, 24], while CHN-AH-2004 only had the 3-nt (TAA) deletion in the 3' UTR [5, 24]. In the present study, 3-nt insertion was not found in UTR for our five obtained PDCoV (data not shown). Moreover, two additional unique features including a 6-nt (TTTGAA) deletion in the nonstructural protein (nsp) 2 region and a 9-nt (GCCGGTTGG) deletion in the nsp 3 region were also found in $\mathrm{CH} /$ Sichuan/S27/2012 [16]. However, for Thai viral isolates, they owned one additional unique nucleotide (C) insertion in the 3' UTR $[17,18]$. The biological significance of these naturally occurring deletions or insertions in $\mathrm{PDCoV}$ biology and pathogenesis warrants further investigations.

In this study, five $\mathrm{S}$ and five $\mathrm{N}$ gene sequences, respectively, were obtained to evaluate wherever genetic diversity of PDCoVs existed in southern China. Our results showed that these five $\mathrm{S}$ and five $\mathrm{N}$ gene sequences were more closely related to Chinese strains, and all clustered together in the phylogenetic tree (Table 2, Figs. 1 and 2). However, $\mathrm{CH} / \mathrm{GD} 01 / 2015$ and $\mathrm{CH} / \mathrm{GD} 02 / 2015$, reported in this study, originated from the same pig farm in Guangdong province, but had $48 \mathrm{nt}$ and $12 \mathrm{nt}$ differences in the $\mathrm{S}$ and $\mathrm{N}$ genes, respectively. The observed 48 nucleotide changes in the $S$ gene made these viruses differ by 25 amino acid residues (Additional file 2: Table $\mathrm{S} 2$ ). For the $\mathrm{N}$ gene, the 12 nucleotide changes among these viruses resulted in 3 amino acid substitutions (Additional file 2: Table S2). Among them, 18 of 25 amino acid differences occurred at the first two-third parts of $S$ gene. Interestingly, in spite of amino acid mutation, both $\mathrm{S}$ and $\mathrm{N}$ protein retained almost consistent amino acid properties (especially $\mathrm{pH}$ value) (Additional file 2: Table S2). Future study will address important roles of these polymorphisms in viral replication and pathogenesis. In addition, they were divided into two distinct small branches (Figs. 1 and 2). These findings suggested that PDCoVs in southern China have diverged from a common ancestor. Despite the emerging genetic diversity, overall, PDCoV prevalence is still largely restricted by the territory as demonstrated in Figs. 1 and 2.

For the two enteric coronaviruses (PEDV and TGEV) in pigs, the recombination events were often detected. However, most of them were from intra-recombination [27-30]. Recently, only one emerging recombinant/chimeric virus (named swine enteric coronavirus, $\mathrm{SeCoV}$ ) was discovered in swine feces and resulted from inter-recombination of PEDV and TGEV, which had a TGEV backbone and a PEDV spike gene [31, 32]. In this study, there were no any possible recombinant events occurring in PDCoV strains. Maybe, the number and length of our obtained PDCoV sequences were limited. In the following study, the recombination event of PDCoV warrants further attentions.

\section{Conclusion}

This study reported the prevalence of PDCoV on swine farms in southern China. Phylogenetic analysis of currently circulating PDCoV strains in this region and other previously reported strains supported the theory of geographical clustering of PDCoV infection landscape. The origin of various PDCoVs in different countries and regions should be further studied. 


\section{Additional files}

Additional file 1: Table S1. Sequence information of PDCoVs and other coronaviruses used in the present study. (DOC $106 \mathrm{~kb}$ )

Additional file 2: Table S2. AA differences of Spike (S) and Nucleocapsid (N) protein between CH/GD01/2015 and CH/GD02/2015. (DOC 42 kb)

\section{Abbreviations}

ELISA, enzyme-linked immunosorbent assay; MEGA, molecular evolutionary genetics analysis; N, nucleocapsid; PBS, phosphate buffered saline; PDCoV, porcine deltacoronavirus; PEDV, porcine epidemic diarrhea virus; PHEV, porcine hemagglutinating encephalomyelitis virus; PRCV, porcine respiratory coronavirus: $R D P$, recombination detection program; Rota $C$, porcine rotavirus group $C$; RT-PCR, reverse transcription polymerase chain reaction; S, Spike; SeCoV, swine enteric coronavirus; TGEV, transmissible gastroenteritis virus; UTR, untranslated region

\section{Funding}

This study was supported by the grants (No. 2013B060500063, No. 2014B040404061, No. 2016A040401012 and No. 201508020055) from Guangdong Provincial Department of Science and Technology and Guangzhou Science Technology and Innovation Commission, respectively. Moreover, this study was also in part supported by USDA/NIFA 2016-67016-24949 (to D.W.). The funding body was not involved into the design of the study, and collection, analysis, and interpretation of data in the manuscript.

\section{Availability of data and materials}

The datasets supporting the conclusions of this article are included within the article and two additional files (Additional file 1: Table S1 and Additional file 2: Table S2).

\section{Authors' contributions}

Shao-Lun Zhai and Wen-Kang Wei conceived the project; Shao-Lun Zhai designed the experiments; Shao-Lun Zhai and Xiao-Peng Li performed most of the experiments; Xiao-Hui Wen and Dian-Hong Lv contributed materials and participated in discussion; Xia Zhou and He Zhang added the data in the revision version; Shao-Lun Zhai wrote the manuscript; Feng Li edited the manuscript; Shao-Lun Zhai and Dan Wang supervised the work. The final version of the manuscript was approved by all authors.

\section{Competing interests}

The authors declare that they have no competing interests.

\section{Author details}

${ }^{1}$ Animal Disease Diagnostic Center, Institute of Animal Health, Guangdong Academy of Agricultural Sciences, Guangdong Key Laboratory of Animal Disease Prevention, Guangdong Open Laboratory of Veterinary Public Health, Guangzhou 510640, China. '2Department of Biology and Microbiology, South Dakota State University, Brookings, SD 57007, USA. ${ }^{3}$ Department of Veterinary and Biomedical Science, South Dakota State University, Brookings, SD 57007, USA.

Received: 26 May 2016 Accepted: 26 July 2016

Published online: 05 August 2016

\section{References}

1. Woo PC, Lau SK, Lam CS, Lau CC, Tsang AK, Lau JH, Bai R, Teng JL, Tsang CC, Wang M, Zheng BJ, Chan KH, Yuen KY. Discovery of seven novel Mammalian and avian coronaviruses in the genus deltacoronavirus supports bat coronaviruses as the gene source of alphacoronavirus and betacoronavirus and avian coronaviruses as the gene source of gammacoronavirus and deltacoronavirus. J Virol. 2012;86:3995-4008.

2. Chen Q, Gauger P, Stafne M, Thomas J, Arruda P, Burrough E, Madson D, Brodie J, Magstadt D, Derscheid R, Welch M, Zhang J. Pathogenicity and pathogenesis of a United States porcine deltacoronavirus cell culture isolate in 5-day-old neonatal piglets. Virology. 2015;482:51-9.

3. Jung $\mathrm{K}, \mathrm{Hu} \mathrm{H}$, Eyerly B, Lu Z, Chepngeno J, Saif LJ. Pathogenicity of 2 porcine deltacoronavirus strains in gnotobiotic pigs. Emerg Infect Dis. 2015;21:650-4.

4. Song D, Moon H, Kang B. Porcine epidemic diarrhea: a review of current epidemiology and available vaccines. Clin Exp Vaccine Res. 2015;4:166-76.
5. Wang L, Hayes J, Sarver C, Byrum B, Zhang Y. Porcine deltacoronavirus: histological lesions and genetic characterization. Arch Virol. 2016;161:171-5.

6. Z Zhang Q, Hu R, Tang X, Wu C, He Q, Zhao Z, Chen H, Wu B. Occurrence and investigation of enteric viral infections in pigs with diarrhea in China. Arch Virol. 2013;158:1631-6.

7. Homwong N, Jarvis MC, Lam HC, Diaz A, Rovira A, Nelson M, Marthaler D. Characterization and evolution of porcine deltacoronavirus in the United States. Prev Vet Med. 2016;123:168-74.

8. Hu H, Jung K, Vlasova AN, Chepngeno J, Lu Z, Wang Q, Saif LJ. Isolation and characterization of porcine deltacoronavirus from pigs with diarrhea in the United States. J Clin Microbiol. 2015;53:1537-48.

9. Lee S, Lee C. Complete Genome Characterization of Korean Porcine Deltacoronavirus Strain KOR/KNU14-04/2014. Genome Announc. 2014;2 e01191-14

10. Li G, Chen Q, Harmon KM, Yoon KJ, Schwartz KJ, Hoogland MJ, Gauger PC Main RG, Zhang J. Full-Length Genome Sequence of Porcine Deltacoronavirus Strain USA/IA/2014/8734. Genome Announc. 2014;2: e00278-14

11. Ma Y, Zhang Y, Liang X, Lou F, Oglesbee M, Krakowka S, Li J. Origin, evolution, and virulence of porcine deltacoronaviruses in the United States. MBio. 2015;6:e00064.

12. Marthaler D, Jiang Y, Collins J, Rossow K. Complete Genome Sequence of Strain SDCV/USA/Illinois121/2014, a Porcine Deltacoronavirus from the United States. Genome Announc. 2014;2:e00218-14.

13. Marthaler D, Raymond L, Jiang Y, Collins J, Rossow K, Rovira A. Rapid detection, complete genome sequencing, and phylogenetic analysis of porcine deltacoronavirus. Emerg Infect Dis. 2014;20:1347-50.

14. Song D, Zhou X, Peng Q, Chen Y, Zhang F, Huang T, Zhang T, Li A, Huang D, Wu Q, He H, Tang Y. Newly emerged porcine deltacoronavirus associated with diarrhoea in swine in China: identification, prevalence and full-length genome sequence analysis. Transbound Emerg Dis. 2015;62:575-80.

15. Wang L, Byrum B, Zhang Y. Detection and genetic characterization of deltacoronavirus in pigs, Ohio, USA, 2014. Emerg Infect Dis. 2014;20:1227-30

16. Wang YW, Yue H, Fang W, Huang YW. Complete Genome Sequence of Porcine Deltacoronavirus Strain CH/Sichuan/S27/2012 from Mainland China. Genome Announc. 2015;3:e00945-15

17. Madapong A, Saeng-Chuto K, Lorsirigool A, Temeeyasen G, Srijangwad A Tripipat T, Wegner M, Nilubol D. Complete Genome Sequence of Porcine Deltacoronavirus Isolated in Thailand in 2015. Genome Announc. 2016;4: e00408-16.

18. Janetanakit T, Lumyai M, Bunpapong N, Boonyapisitsopa S, Chaiyawong S, Nonthabenjawan N, Kesdaengsakonwut S, Amonsin A. Porcine deltacoronavirus, Thailand, 2015. Emerg Infect Dis. 2016;22:757-9.

19. Wang L, Byrum B, Zhang Y. Porcine coronavirus HKU15 detected in 9 US states, 2014. Emerg Infect Dis. 2014;20:1594-5.

20. Hu X, Li N, Tian Z, Yin X, Qu L, Qu J. Molecular characterization and phylogenetic analysis of transmissible gastroenteritis virus $H X$ strain isolated from China. BMC Vet Res. 2015:11:72.

21. Sun R, Leng Z, Zhai SL, Chen D, Song C. Genetic variability and phylogeny of current Chinese porcine epidemic diarrhea virus strains based on spike, ORF3, and membrane genes. ScientificWorldJournal. 2014;2014:208439.

22. Jeong YJ, Park SI, Hosmillo M, Shin DJ, Chun YH, Kim HJ, Kwon HJ, Kang SY, Woo SK, Park SJ, Kim GY, Kang MI, Cho KO. Detection and molecular characterization of porcine group C rotaviruses in South Korea. Vet Microbiol. 2009;138:217-24.

23. Chen F, Zhu Y, Wu M, Ku X, Yao L, He Q. Full-Length Genome Characterization of Chinese Porcine Deltacoronavirus Strain CH/SXD1/2015. Genome Announc. 2015;3:e01284-15.

24. Dong N, Fang L, Zeng S, Sun Q, Chen H, Xiao S. Porcine deltacoronavirus in Mainland China. Emerg Infect Dis. 2015;21:2254-5.

25. McCluskey BJ, Haley C, Rovira A, Main R, Zhang Y, Barder S. Retrospective testing and case series study of porcine delta coronavirus in U.S. swine herds. Prev Vet Med. 2016;123:185-91.

26. Thachil A, Gerber PF, Xiao CT, Huang YW, Opriessnig T. Development and application of an ELISA for the detection of porcine deltacoronavirus IgG antibodies. PLoS One. 2015;10:e0124363.

27. Jarvis MC, Lam HC, Zhang Y, Wang L, Hesse RA, Hause BM, Vlasova A, Wang Q, Zhang J, Nelson MI, Murtaugh MP, Marthaler D. Genomic and evolutionary inferences between American and global strains of porcine epidemic diarrhea virus. Prev Vet Med. 2016;123:175-84. 
28. Li B, Liu H, He K, Guo R, Ni Y, Du L, Wen L, Zhang X, Yu Z, Zhou J, Mao A, Lv L, Hu Y, Yu Y, Zhu H, Wang X. Complete genome sequence of a recombinant porcine epidemic diarrhea virus strain from eastern china. Genome Announc. 2013;1:e0010513.

29. Li R, Qiao S, Yang Y, Guo J, Xie S, Zhou E, Zhang G. Genome sequencing and analysis of a novel recombinant porcine epidemic diarrhea virus strain from Henan. China Virus Genes. 2016;52:91-8.

30. Tian PF, Jin YL, Xing G, Qv LL, Huang YW, Zhou JY. Evidence of recombinant strains of porcine epidemic diarrhea virus, United States, 2013. Emerg Infect Dis. 2014;20:1735-8.

31. Akimkin V, Beer M, Blome S, Hanke D, Höper D, Jenckel M, Pohlmann A. New Chimeric Porcine Coronavirus in Swine Feces, Germany, 2012. Emerg Infect Dis. 2016;22:doi:10.3201/eid2207.160179.

32. Boniotti MB, Papetti A, Lavazza A, Alborali G, Sozzi E, Chiapponi C, Faccini S, Bonilauri P. Cordioli P. Marthaler D. Porcine epidemic diarrhea virus and discovery of a recombinant swine enteric coronavirus, Italy. Emerg Infect Dis. 2016;22:83-7.

Submit your next manuscript to BioMed Central and we will help you at every step:

- We accept pre-submission inquiries

- Our selector tool helps you to find the most relevant journal

- We provide round the clock customer support

- Convenient online submission

- Thorough peer review

- Inclusion in PubMed and all major indexing services

- Maximum visibility for your research

Submit your manuscript at www.biomedcentral.com/submit 